\title{
A SIMPLIFIED MULTI-CRITERIA EVALUATION MODEL FOR LANDFILL SITE RANKING AND SELECTION BASED ON AHP AND GIS
}

\author{
Debishree KHAN, Sukha Ranjan SAMADDER \\ Department of Environmental Science \& Engineering, Indian School of Mines, Dhanbad-826004, India
}

Submitted 04 Feb. 2015; accepted 27 May 2015

\begin{abstract}
This study used GIS based Multi-criteria Decision Analysis (MCDA) approach for evaluating the most environmentally suitable landfill sites in the study area. The weights of relative importance of the factors guiding landfill siting were estimated using pair-wise comparisons in AHP. The maps showing suitable landfill sites were generated applying a weighted linear combination (WLC) in GIS using a comparison matrix to aggregate different significant scenarios associated with environmental and economic objectives. To determine the appropriate areas where landfill sites can be located, thematic maps for all the criteria were generated using GIS. A final map was produced showing suitability for the location of the landfill sites. The suitable sites having an area equal to or above 4 ha at one place and $90 \%$ of which is barren land were considered suitable for landfill. The selected candidate sites were ranked to get the most desirable sites for landfill.
\end{abstract}

Keywords: analytic hierarchy process, Dhanbad, geographical information system, landfill siting, multi-criteria decision making, municipal solid waste, weighted linear combination.

\section{Introduction}

Municipal Solid Waste Management (MSWM) in developing nations is one of the biggest environmental challenges due to rapid population growth that demands more and more suitable sites for municipal solid waste disposal. The generation of MSW is an unavoidable result of human activity which involves the generation, onsite storage, collection, transfer and transportation, recycling, treatment and disposal (Chiueh, Yu 2006). Waste generation is the result of inefficient and unsustainable uses of natural resources and energy in production processes, which leads to economic and environmental problems, such as large additional expenses for the collection, processing and waste landfilling and elimination (Schiopu et al. 2012; Simion et al. 2013). Unfortunately, materials resulting from construction and demolition are often considered as waste for disposal, rather than resources for processing and reuse. They have negative impacts on environment, economy, public health, and social life (Ionescu et al. 2011; Robu et al. 2007). The management of Municipal Solid Waste (MSW) is going through a critical phase due to the unavailability of suitable facilities for treatment and disposal of large amounts of MSW generated in metropolitan cities. Unscientific disposal causes adverse impacts on all aspects of the environment and human health (Rathi 2006;
Sharholy et al. 2008). In India, it is very often observed that due to limited availability of land and lack of regulatory measures, the MSW is disposed-off on low-lying areas without taking any precautions or operational controls. The present practice of MSWM demands an environment friendly and suitable landfill sites for waste management in fast growing regions of developing nations as the landfill is the most common method for disposal of MSW. The "not in my backyard" (NIMBY) and "not in anyone's backyard" (NIABY) concepts (Chang et al. 2008; Kontos et al. 2003) are popular in most cities of developing nations that create problems for the decision makers involved in MSWM.

An inappropriate landfill site may have negative impacts on the environment. Therefore, it should be selected carefully by considering both regulatory requirements and other constraints (Şener 2004). The siting of MSW landfill is a spatial multi-criteria decision analysis (SMCDA) for which both GIS and MCDA methods should be used (Kontos et al. 2005). Some relevant studies on landfill siting and solid waste management have integrated GIS and MCDA in various ways which also include analytic hierarchy process(AHP) using weighted linear combination (WLC) (Carver 1991; Siddiqui et al. 1996; Charnpratheep et al. 1997; Kao et al. 1997; Lukasheh et al. 2001; Kontos et al. 2003, 2005; Higgs 2006; Şener et al. 2006;

Corresponding author: Sukha Ranjan Samadder

E-mail: sukh_samadder@yahoo.co.in 
Chang et al. 2008; Delgado et al. 2008; Wang et al. 2009; Şener et al. 2010; Kara, Doratli 2012; Yildirim 2012; Achillas et al. 2013; Allesch, Brunner 2014; Demosouka et al. 2014).

The present paper has considered the ranking of selected candidate landfill sites using linear combination of weights derived from AHP which has not been done in earlier studies on landfill site selection. This study will help the municipal engineers to get the most precise environmentally sound landfill sites with suitability ranking. Siting decisions are governed by the pre-existing land use dynamics of the urban area as well as the nature of potential interactions of the landfill with the pre-existing environmental, geologic, hydrological, and socioeconomic parameters of the area (Sumathi et al. 2008). Siddiqui et al. (1996) were among the first to integrate GIS and AHP for landfill siting. This integration plays a significant role in siting landfills for solid waste management. Complex geographical data can be represented by thematic layers and correlation among large volumes of discrete geographical information can be attributed together to provide the demand of the investigators. Hence GIS and remote sensing techniques can be applied in the field of MSWM using a multi-criteria decision making technique to provide the organized approach for assessing and integrating the impact of various factors as indicators of suitability of landfill sites.

On the other hand AHP is a powerful tool for solving complicated problems that may have interactions and correlations among multiple objectives. This technique provides a means of decomposing the problem into a hierarchy of sub-problems that can be more easily comprehended and subjectively evaluated. The subjective evaluations are converted into numerical values that are ranked on a numerical scale (Bhushan, Rai 2004). This present study examined the applicability of the GIS techniques in combination with a multi-criteria approach for analyzing the land suitability for landfill. The most prevalent procedure for integrating multi-criteria evaluation and multi-objective evaluation (MOE) in GIS for land suitability analysis is WLC approach (Hopkins 1977). The WLC procedure allows full trade off among all factors and offers much more flexibility than the Boolean approaches. Most of these methods were developed for case studies by considering the regionalised social and geo-environmental criteria. The generalised global method might not be an appropriate method for landfill suitability at regional level as there are lots of evaluation criteria mentioned in the literature but their existence vary from region to region. Previous studies have considered many more criteria to make the selection process more precise but the main challenges in this study were the unavailability and proper applicability of the data. The purpose of this study was to locate the suitable landfill sites in Dhanbad city, Jharkhand, India for
MSW disposal using AHP and WLC approach by considering various localized factors that may influence locating landfill sites in the study area. The criteria which were having more environmental impact and appropriate for the present study area were only considered in the study to keep the methodology simple so that decision makers can easily adopt the proposed methodology. Different standardized scales were used in the process of assigning the weightage to each one of the criteria of landfill siting and a ranking process was adopted to get the candidate site ranking order.

\section{Materials and methodology}

\subsection{Study area}

Dhanbad is one of the mineral rich (especially coal reserves) districts of India located in the state of Jharkhand. The region lies on the eastern part of Chhotanagpur plateau and has an undulating topography. The study area extends from $86^{\circ} 06^{\prime} 11^{\prime \prime} \mathrm{E}$ to $86^{\circ} 50^{\prime} 26^{\prime \prime}$ E longitude and from $23^{\circ} 38^{\prime} 58^{\prime \prime} \mathrm{N}$ to $24^{\circ} 03^{\prime} 30^{\prime \prime} \mathrm{N}$ latitude (Fig. 1). Present study area covers the main agglomerated urban region of the city within Dhanbad Municipal Corporation (DMC), consisting of 24 administrative wards. The total area of the present study region is about $101 \mathrm{~km}^{2}$ that supports about 0.49 million population as per census of India, 2011. The density of population was estimated to be 2947 persons $/ \mathrm{km}^{2}$ and it is rising at an annual rate of $1.5 \%$. The study area mainly consists of residential area, agricultural area, scrubs and quarry areas. It has considerable scope of expansion and may alter the land-use pattern in the near future for which overall planning of municipal facilities including municipal solid waste management in the city as a whole is required. The economic growth in the study area due to the extraction of mineral reserves has led to a rapid growth in population and change in land-use pattern that resulted in increase of solid waste generation. At present the study area has neither any proper demarcated landfill sites, nor any organized method of solid waste disposal.

\subsection{Pre-processing of data}

The present study requires satellite images, toposheets containing ground information, local administrative maps, and field observation data. Prior to the beginning of suitability analysis, the data were corrected and processed to facilitate GIS functionality of the data. To perform a land-use/landcover mapping, atmospheric correction and precise geometric registration of images with location accuracy is a pre-requisite. Atmospheric scattering contributes some additional spectral values to the ground reflectance (Jensen 1986). In this study, the LISS IV image was corrected for atmospheric path 
radiance using dark object subtraction method (Chavez 1988). These images were geometrically corrected by taking well distributed Ground Control Points (GCPs) that were extracted from topographical maps of the study area. The PAN images were registered with the LISS IV images up to the sub-pixel accuracy. The preprocessed images were pan sharpened before the landuse classification method was used as a pan sharpened image gives best of both the images with high spectral resolution (multi-spectral image) and high spatial resolution (panchromatic image). In this study interactive visual interpretation method was applied to classify the pan-sharpened LISS IV image into existing land-use. Some land-use units were recorded using the reference from high resolution Google Earth image to make the land-use map more precise. The land-use map of the present study area is shown in Figure 2.

Slope, aspect and flow accumulation were derived from Carto-DEM of the study area, road map, groundwater depth map and soil map were extracted from PAN image, CGWB (Central Ground Water Board, India) map and NBSS (National Bureau of Soil Survey, India) map respectively. Landuse related criteria layers were extracted from the land-use map prepared from the pan sharpened LISS IV image.

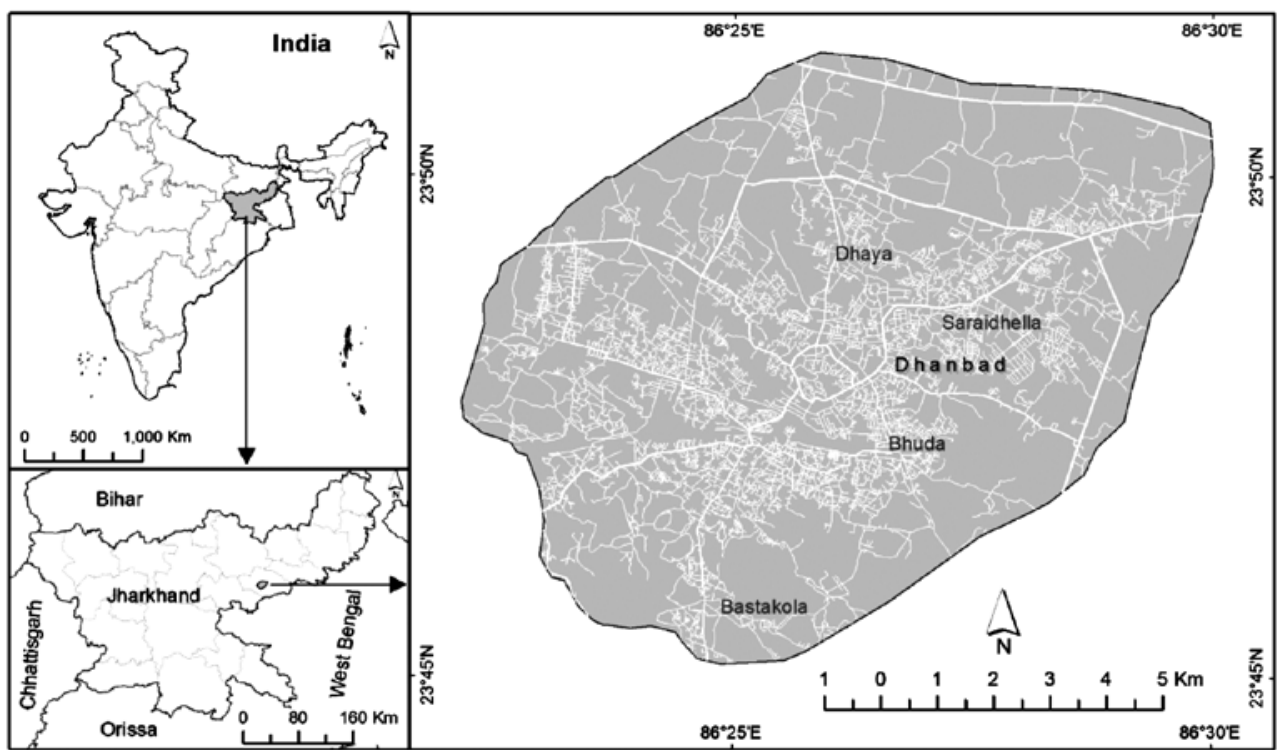

Fig. 1. Location of the study area

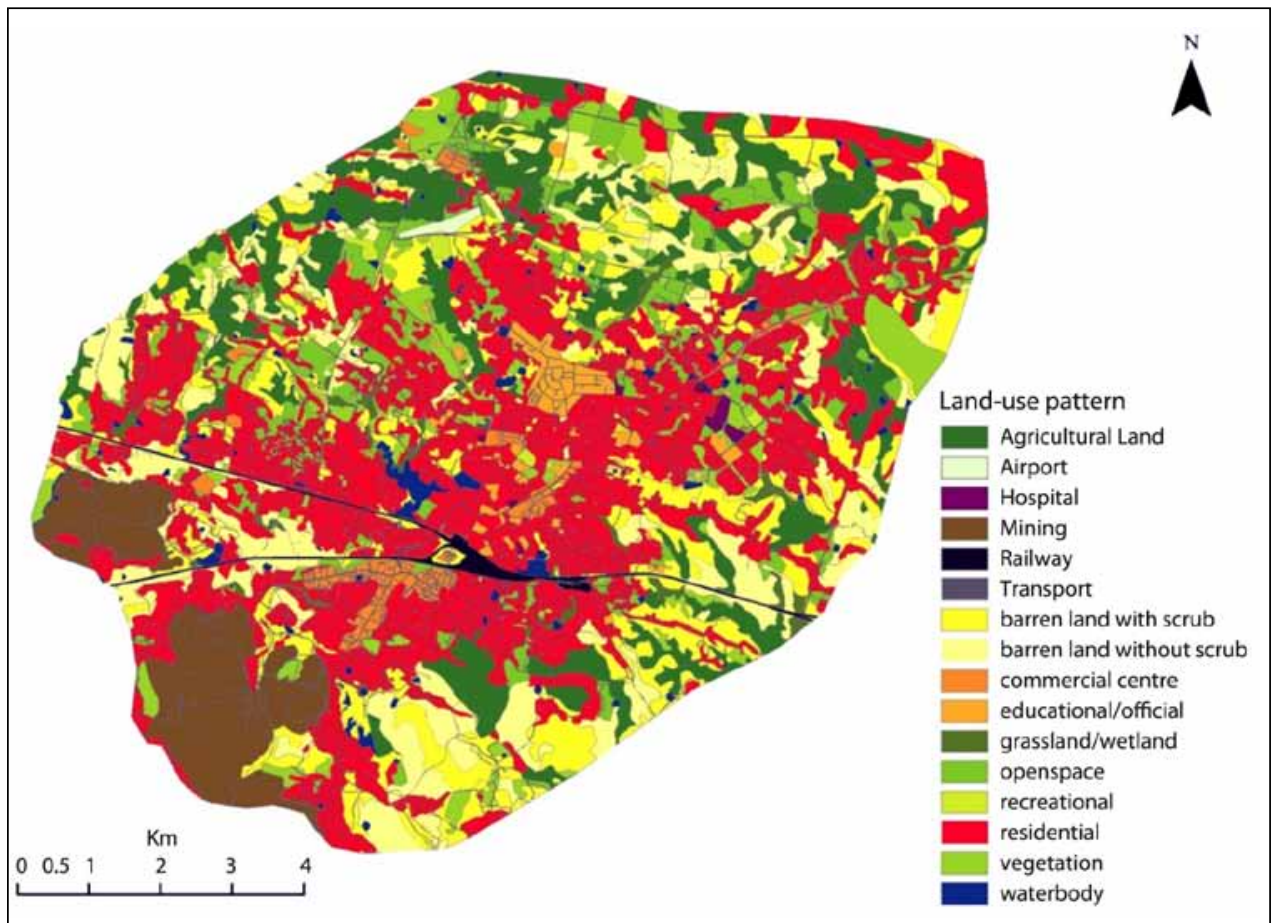

Fig. 2. Land-use of the study area 


\subsection{Methodology}

The stepwise operational methodology used in this study is portrayed in Figure 3 and explained in detail in the following sections:

\subsubsection{Multi-criteria evaluation}

Spatial multi-criteria decision making (MCDM) is a process where geographical data are combined and transformed into a decision. It involves input data, the decision makers' performances and manipulation of both information using specified decision rules. The actual process of applying the decision rule is evaluation. In order to meet the objective, several criteria need to be evaluated and is termed as Multi-Criteria Evaluation (MCE).
A variety of scales on which criteria and sub-criteria can be measured.

MCDA requires the values contained in the various criterion map layers to be transformed into comparable units (Moeinaddini et al. 2010). Criteria maps can be classified on the basis of the types of available information for map construction. In order to compare criteria with each other, all units were transformed into the same unit of measurement scale. Standardization was done by assigning a numeric value between 1 and 5, where 1 signified the maximum suitability rate and 5 as the not suitable for each criterion (Table 1). Each of the criteria was standardized based on expert opinions considering the potentiality of the land for landfill site and then each of the prepared layers was evaluated in GIS platform.

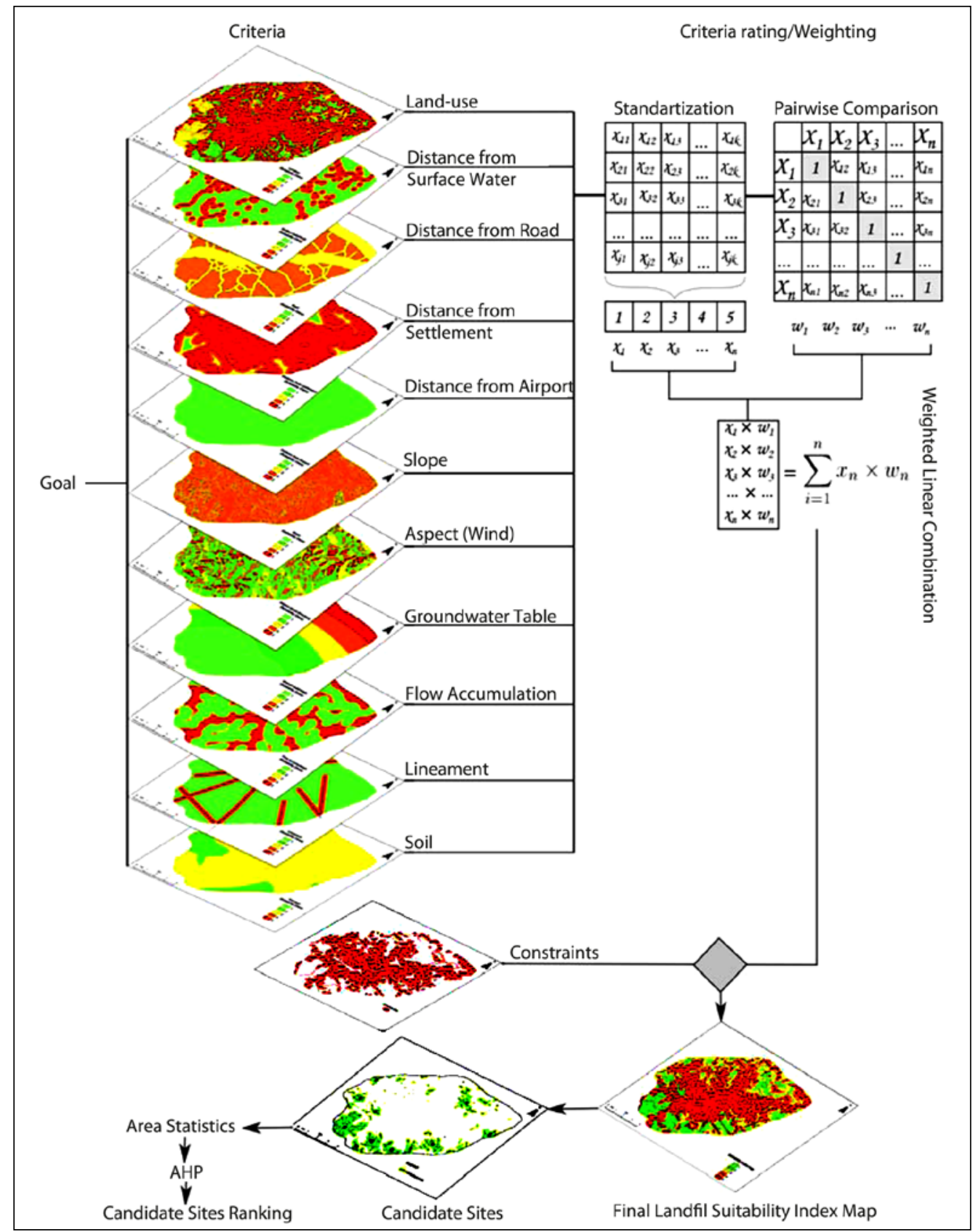

Fig. 3. Methodology of the study 


\subsubsection{Assigning criteria weights}

AHP is one of the multiple criteria decision-making methods that were originally developed by Saaty (1977). It has the capability to simplify preference ratings among decision criteria using pair-wise comparisons. The AHP technique is used to evaluate each criterion as multiple important objectives are difficult to prioritize. The weights of specific criteria are assigned using Saaty's technique (Saaty 1977), in which a ratio (reciprocal) matrix is constructed where each criterion is compared with the other criteria, relative to its importance on a scale with values from a set $\{1 / 9,1 / 8,1 / 7$, $1 / 6,1 / 5,1 / 4,1 / 3,1 / 2,1,2,3,4,5,6,7,8,9\}$, ranging from the minimum value of $1 / 9$ representing the least important, to 1 for equal importance and to 9 for the most important.

The weights are calculated by normalizing the eigenvector associated with the maximum eigen-value of the matrix.

The calculation involves the following steps: (a) computation of sum of values in each column of pair-wise matrix, (b) normalization of the matrix by dividing each element by its column total, (c) computation of mean of the elements in each row of the normalized matrix.

Then the consistency ratio (CR) is computed to check the consistency of comparisons using the Eq. (1) and Eq. (2).

$$
\begin{gathered}
C I=\frac{\lambda_{\text {max }}-n}{n-1} ; \\
C R=\frac{C I}{R I},
\end{gathered}
$$

where $\lambda_{\max }=$ Principal eigen value $=$ sum of the products between each element of the priority vector and column total, $n=$ number of criteria. $C I=$ consistency index and $R I=$ random inconsistency index.

If the consistency ratio $(C R)$ is greater than 0.10 , then some pair-wise values need to be reconsidered till the desired value of $C R<0.10$ is reached.

After standardization of criteria and determination of relative weights of each of the criteria in landfill site selection process, the next step is to aggregate them to obtain the suitability of the land for the purpose. WLC method is the widely used method for aggregation of standardized criteria and their weights in suitability assessment process. Weighted maps and constraints maps were aggregated in the present study to obtain the final suitability due to the obvious reasons that these are the land-use patterns that cannot be disturbed for such planning. Empirically see Eq. (3):

$$
S=\sum_{i=1}^{n} w_{i} \cdot x_{i} \prod_{j=1}^{m} c_{j},
$$

where $S=$ Composite suitability score, $x_{i}=$ Criterion score, $w_{i}=$ Weight assigned to each criterion, $c_{j}=$ Constrains, $\sum=$ Sum of Weights and $\prod=$ Products of the constraints.
Final candidate sites were chosen from final suitability map which had area greater than a threshold value of 4 ha, the minimum area required for a service period of 20 years (Manual on Municipal... 2000). So, the areas below the threshold value were considered as not suitable for landfill. Then all candidate sites were ranked based on comparative statistical analysis of area occupied by each attributes of three main criteria i.e. land-use pattern, distance from settlement, and distance from water bodies. Further an AHP was constructed to pool three rank vectors in one rank vector to prioritize the selected candidate sites.

\section{Results and discussion}

\subsection{Site selection criteria}

In this study, eleven possible criteria were selected for evaluating landfill suitability which includes the major environmental and socio-economic parameters of the study area (land-use pattern, slope, distance from the settlement, distance from water bodies, depth of groundwater table, lineament, wind orientation, flow accumulation, distance from roads, distance from airport and soil type). Figure 4 shows suitability maps for all the criteria that were considered for the present study and Table 1 shows the classes of each criterion and their standardized score (rating).

The weights were assessed taking the feasibility and possibility of modifying the natural conditions of the sites by appropriate engineering intervention, so as to increase their suitability (as was done by Delgado et al. 2008). These criteria are discussed below:

\subsubsection{Slope}

Lin, Kao (1998) have suggested that the appropriate slope for constructing a landfill is about $8-12 \%$, because too steep slope would make it difficult to construct and maintain and too flat of a slope would affect the drainage. A slope above $12 \%$ creates high runoff rates for precipitation. With higher runoff rate and decreased infiltration, contaminants may travel greater distances from the containment area. Topographically the present study area is a lower plateau having relatively little undulations. The general slope is from North West to South East direction. The criteria were graded as per the suitability class and ranked accordingly. A slope range of $8-16 \%$ was considered to be the most preferable for the landfill site and hence assigned gradel in the present study.

\subsubsection{Distance from roads}

The landfill must not be located within $200 \mathrm{~m}$ of any major highways and city streets and $500 \mathrm{~m}$ of a railway line (Şener et al. 2006). On the other hand, the landfill site should not be placed too far from the existing road 
networks for reducing the cost of new road construction, transportation and collection costs of solid wastes. In the present study, buffer zones were created taking the radial distance of 100, 200, 300, 400, 500 meters respectively and suitable grades were assigned.

\subsubsection{Land-use}

The land-use characterizes a degree of economic activities and population density associated with the area under study. The different land-use types were assigned different weights considering their respective economic activities and the population density. The residential or other settlement areas, recreational areas, vegetation and the airport were considered inappropriate for MSW landfill siting and therefore, were assigned relatively high grade to discard the area for landfilling and the area which is exclusively barren land and barren land with some scrubs were considered as suitable for such activity and hence was assigned grades 1 and 2 respectively. The other land-use types were assigned grades as per their relative importance.

\subsubsection{Distance from settlement}

The landfill site should not be in the vicinity of the residential or an urban area to avoid adverse impact on land value and future development and to protect the people from possible environmental hazards of landfill sites. The landfill must be located within $10 \mathrm{~km}$ of an urban area (Baban, Flannagan 1998) but should not be within $1 \mathrm{~km}$ of

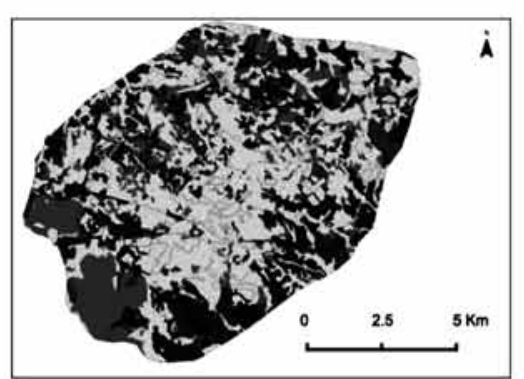

a) Land-use

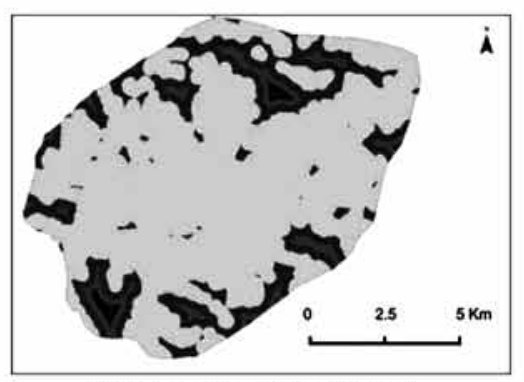

d) Distance from Settlement

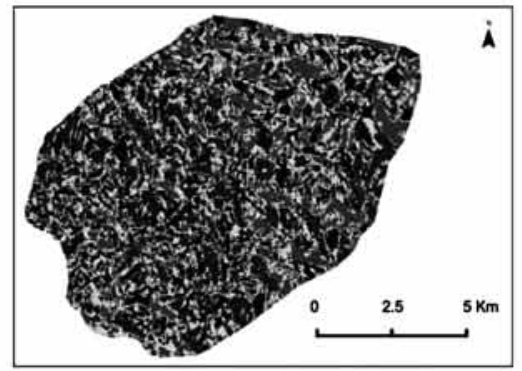

g) Aspect (Wind Orientation)

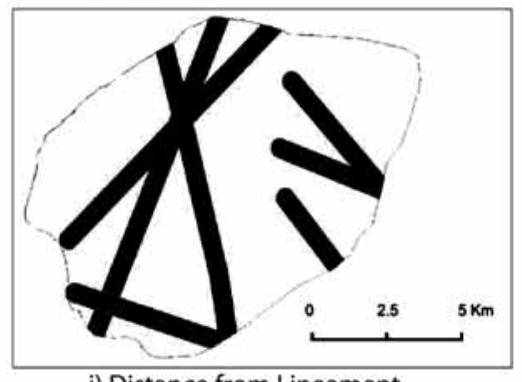

j) Distance from Lineament

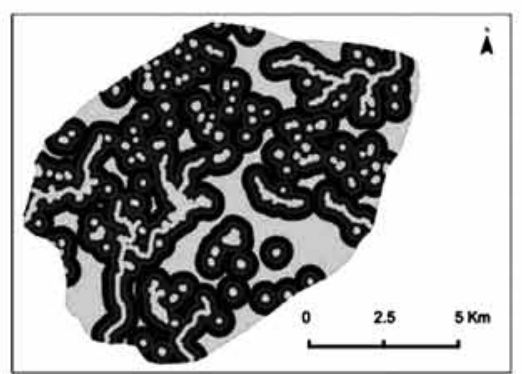

b) Distance from Surface Waterbody

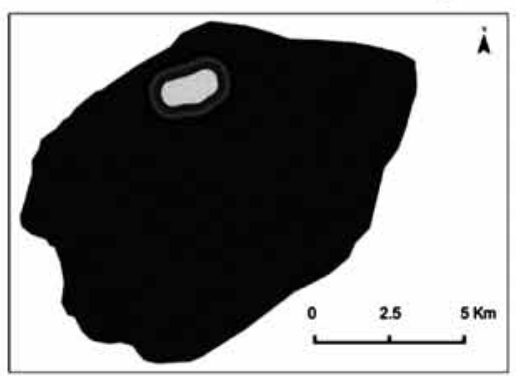

e) Distance from Airport

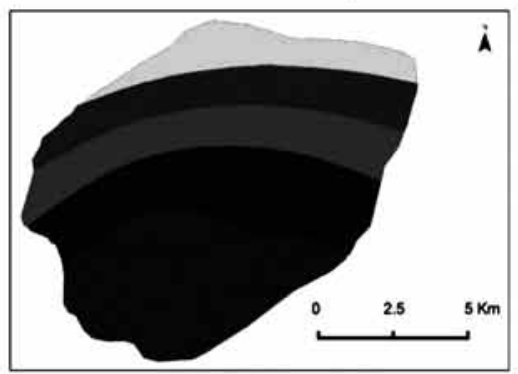

h) Depth to Groundwater

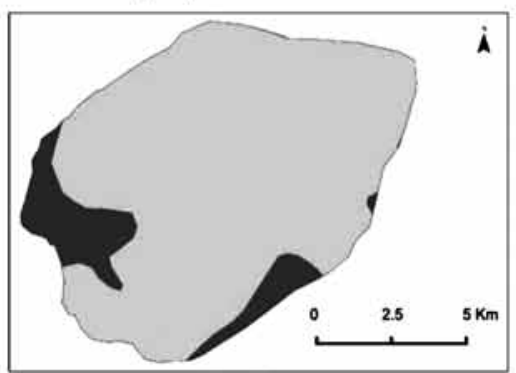

k) Soil Type

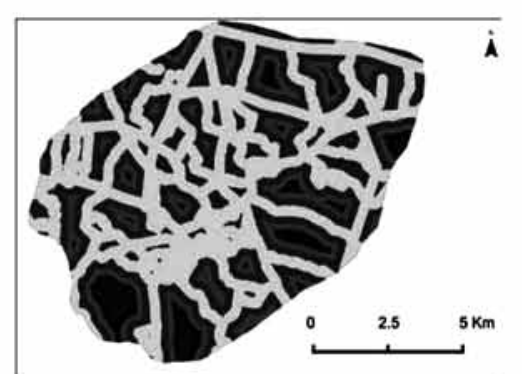

c) Distance from Road

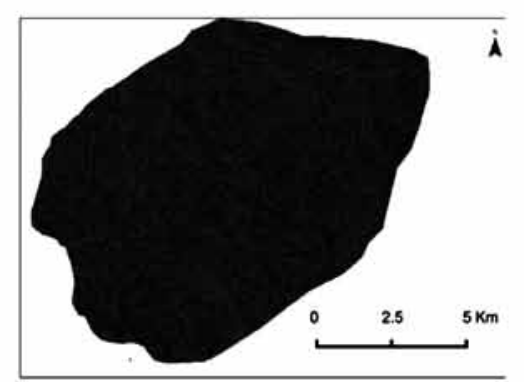

f) Slope

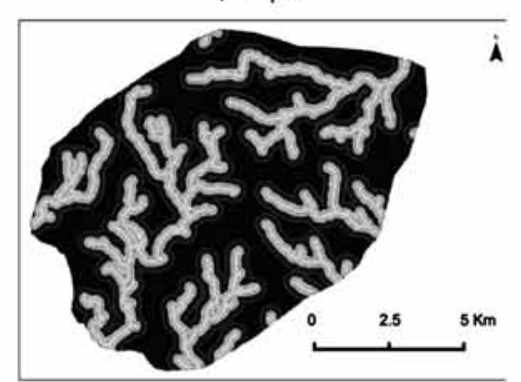

i) Flow Accumulation

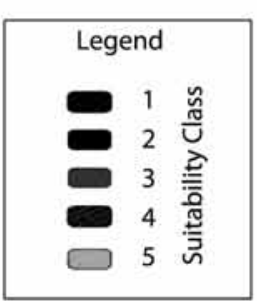

Fig. 4. Suitability map of all the selected criteria 
an urban area as per Turkish Solid Waste Control Regulations (TSWCR 2002). A distance of more than or equal to $500 \mathrm{~m}$ from settlement was taken as suitable for landfill siting in the present study (consistent with Demesouka et al. 2014).

\subsubsection{Depth to groundwater}

A landfill site should be located in an area where groundwater is sufficiently deep, so that the groundwater quality is not affected due leachate movement from landfill sites. Keeping this in mind, zones with varying water-table depth were demarcated and grades were assigned in such a way that the zone with maximum depth was considered most suitable and vice-versa to avoid the area with groundwater table near the surface. The depth of groundwater table from ground surface was reclassified in a depth range varying from $0-2 \mathrm{~m}, 2-2.5 \mathrm{~m}, 2.5-3 \mathrm{~m}, 3-3.5 \mathrm{~m}$, 3.5-4 $\mathrm{m}$ and each range was standardise based on their suitability. Groundwater depth more than 3.5 metres from ground surface was considered safe for constructing landfill (Manual on Municipal... 2000) in the present study.

\subsubsection{Lineament}

Faults are geological structures that restrict the siting of a safe landfill site (Gemitzi et al. 2007) as these allow the leachate to flow quickly to reach groundwater. The landfill site should be located at least 100-200 m away from any faults, fissures, joints, stream/lakes and other shear zones avoid the groundwater pollution of any area (Demesouka et al. 2014). All the lineaments were buffered by a distance interval of $0-100 \mathrm{~m}$. According to the calculations in the present study, the areas located at more than $400 \mathrm{~m}$ away from the lineaments had the lowest weight values (most suitable), but those $<100 \mathrm{~m}$ from the lineaments had the highest gradevalues (least suitable).

\subsubsection{Wind orientation}

Settlements near the landfill get affected by odour generated from the landfill; hence it is always preferable to site the location of a landfill at a place where wind direction is not towards the settlement and away from the settlement zone. To evaluate the wind direction of the study area, an aspect map was prepared using DEM (as suggested by Şener et al. 2010). The hillsides located in the windward direction relative to the settlements were assigned a lower grade. The northeast (NE) and southwest (SW) winds were the dominant wind direction; hence the hillsides located in NE-SW and flat areas were assigned a grade 5 in the present study area, because they were more exposed to the wind and thus unsuitable. The other hillsides were assigned lower grades, depending on their wind frequency and suitability in the study area.
Table 1. Reclassified criteria and their rating

\begin{tabular}{|c|c|c|}
\hline Criteria & Class & Rating \\
\hline \multirow{5}{*}{ Land-use } & Barren land without scrub & 1 \\
\hline & Barren land with scrub & 2 \\
\hline & Mining, Open space & 3 \\
\hline & Vegetation, Grassland, wetland & 4 \\
\hline & $\begin{array}{l}\text { Agriculture, Surface water } \\
\text { body, Settlements }\end{array}$ & 5 \\
\hline \multirow{5}{*}{ Slope } & $8-12 \%$ & 1 \\
\hline & $12-16 \%$ & 2 \\
\hline & $4-8 \%$ & 3 \\
\hline & $16-20 \%$ & 4 \\
\hline & $>20 \%$ & 5 \\
\hline \multirow{5}{*}{$\begin{array}{l}\text { Distance } \\
\text { from } \\
\text { settlement }\end{array}$} & $0-200 \mathrm{~m}$ & 5 \\
\hline & $200-400 \mathrm{~m}$ & 4 \\
\hline & $400-600 \mathrm{~m}$ & 3 \\
\hline & $600-800 \mathrm{~m}$ & 2 \\
\hline & $>800 \mathrm{~m}$ & 1 \\
\hline \multirow{5}{*}{$\begin{array}{l}\text { Distance } \\
\text { from surface } \\
\text { water body }\end{array}$} & $0-100 \mathrm{~m}$ & 5 \\
\hline & $100-200 \mathrm{~m}$ & 4 \\
\hline & $200-300 \mathrm{~m}$ & 3 \\
\hline & $300-400 \mathrm{~m}$ & 2 \\
\hline & $400-500 \mathrm{~m}$ & 1 \\
\hline \multirow{5}{*}{$\begin{array}{l}\text { Depth of } \\
\text { groundwater }\end{array}$} & $0-2 \mathrm{~m}$ & 5 \\
\hline & $2-2.5 \mathrm{~m}$ & 4 \\
\hline & $2.5-3 \mathrm{~m}$ & 3 \\
\hline & $3.3-5 \mathrm{~m}$ & 2 \\
\hline & $3.5-4 \mathrm{~m}$ & 1 \\
\hline \multirow{5}{*}{$\begin{array}{l}\text { Lineament } \\
\text { density }\end{array}$} & $0-100 \mathrm{~m}$ & 5 \\
\hline & $100-200 \mathrm{~m}$ & 4 \\
\hline & $200-300 \mathrm{~m}$ & 3 \\
\hline & $300-400 \mathrm{~m}$ & 2 \\
\hline & $>400 \mathrm{~m}$ & 1 \\
\hline \multirow{5}{*}{ Aspect } & South West & 1 \\
\hline & North East & 2 \\
\hline & South East & 3 \\
\hline & North West & 4 \\
\hline & North, South, East, West & 5 \\
\hline \multirow{5}{*}{$\begin{array}{l}\text { Flow } \\
\text { accumulation }\end{array}$} & $0-600$ cells & 1 \\
\hline & $600-2500$ cells & 2 \\
\hline & $2500-6000$ cells & 3 \\
\hline & $6000-15000$ cells & 4 \\
\hline & $15000-32473$ cells & 5 \\
\hline \multirow{5}{*}{$\begin{array}{l}\text { Distance } \\
\text { from road }\end{array}$} & $500 \mathrm{~m}$ & 1 \\
\hline & $400 \mathrm{~m}$ & 2 \\
\hline & $300 \mathrm{~m}$ & 3 \\
\hline & $200 \mathrm{~m}$ & 4 \\
\hline & $100 \mathrm{~m}$ & 5 \\
\hline \multirow{5}{*}{$\begin{array}{l}\text { Distance } \\
\text { from airport }\end{array}$} & $0-200 \mathrm{~m}$ & 5 \\
\hline & $200-400 \mathrm{~m}$ & 4 \\
\hline & $400-600 \mathrm{~m}$ & 3 \\
\hline & $600-800 \mathrm{~m}$ & 2 \\
\hline & $800-1000 \mathrm{~m}$ & 1 \\
\hline \multirow{2}{*}{ Soil type } & Loamy to fine & 2 \\
\hline & Loamy to Loamy & 3 \\
\hline
\end{tabular}




\subsubsection{Flow accumulation}

A flow accumulation raster calculates the number of cells that will contribute flow into each cell of the study area (O'Callaghan, Mark 1984). It determines the size of the region over which water from precipitation (rainfall, snowfall, etc.) can be accumulated. It also depicts the contributing area of a watershed and is highly correlated with both its surface runoff and peak discharge. The high flow accumulated areas were demarcated as not suitable to avoid the direct impact of surface runoff in the present study.

\subsubsection{Distance from water bodies}

Landfills release noxious gases and leachate. So they should not be in proximity to water wells and surface water bodies (Dorhofer, Siebert 1998). Weights were assigned using AHP in similar way as was done for roads. The distance from the water bodies was buffered at a distance varying from 0-100 m, 100-200 m, 200-300 m, 300-400 m, 400$500 \mathrm{~m}$. The distance from the water bodies more than 500 metres was considered safe for constructing landfill in the present study area (Manual on Municipal... 2000).

\subsubsection{Distance from airport}

The distance between an airport and landfill site should be a minimum of $3 \mathrm{~km}$ for safety measures (Wang et al. 2009). Another reason for locating a landfill away from the airport is to avoid birds that easily get attracted to landfill sites due to availability of different types of food wastes (Moeinaddini et al. 2010). Recently in a study, Gbanie et al. (2013) formed a $0.5 \mathrm{~km}$ buffer zone from helipads in the examined area. The distance of landfill from airport was taken $1 \mathrm{~km}$ as the most suitable one in this area as the airport is not in use on the regular basis and the area proposed for the airport is not sufficient, hence further development of the airport may not be possible.

\subsubsection{Soil type}

Soil should be of sufficiently low permeability to ensure very slow movement of leachate from the site towards groundwater. Thus, sites on clayey soil having low permeability should be preferred. A landfill constructed over a permeable formation such as gravel, sand or fractured bedrock can pose a significant threat to groundwater quality. The present study area has two dominant types of soils and they are fine loamy to fine and fine loam to loamy. Fine loamy to fine was considered to be more suitable for landfill site and grade accordingly due to its low permeability over the other type soil present in the study area.

\subsection{Final landfill site suitability analysis}

For selection of potential landfill sites in the present study, AHP was used after detail evaluation of the various criteria of landfill siting. Pair-wise comparison method was used only to assign weights and to set up the significance of environmental criteria (Table $2 a$ ) using AHP where highest weightage was assigned to the land-use pattern. Then the column total is derived and the cell values of each column are divided by its respective column total to get a normalized value matrix as given in Table $2 \mathrm{~b}$. Finally the weights were calculated by taking the average values of the row for each criteria. The detail calculation steps were same as discussed in the methodology section.

The CR value of all comparisons was lower than 0.1 that indicated the use of weights was suitable (consistent with Eastman 2003).

WLC was applied to aggregate all criteria and display potential landfill sites considering all the criteria and their relative weights for each of the criteria and accordingly an intermediate suitability maps were

Table 2a. Comparison matrix for the site selection criteria

\begin{tabular}{|c|c|c|c|c|c|c|c|c|c|c|c|}
\hline Parameters & $x_{1}$ & $x_{2}$ & $x_{3}$ & $x_{4}$ & $x_{5}$ & $x_{6}$ & $x_{7}$ & $x_{8}$ & $x_{9}$ & $x_{10}$ & $x_{11}$ \\
\hline Land-use $\left(x_{1}\right)$ & 1 & 2 & 3 & 3 & 4 & 4 & 5 & 4 & 5 & 8 & 9 \\
\hline Slope $\left(x_{2}\right)$ & $1 / 2$ & 1 & $1 / 3$ & 2 & 4 & 5 & 6 & 3 & 6 & 8 & 8 \\
\hline Distance from settlement $\left(x_{3}\right)$ & $1 / 3$ & 3 & 1 & 2 & 4 & 3 & 4 & 3 & 6 & 7 & 9 \\
\hline Distance from waterbody $\left(x_{4}\right)$ & $1 / 4$ & $1 / 2$ & $1 / 2$ & 1 & 3 & 2 & 6 & 4 & 7 & 6 & 8 \\
\hline Groundwater $\left(x_{5}\right)$ & $1 / 4$ & $1 / 4$ & $1 / 4$ & $1 / 3$ & 1 & 3 & 2 & 3 & 3 & 3 & 8 \\
\hline Lineament $\left(x_{6}\right)$ & $1 / 5$ & $1 / 5$ & $1 / 3$ & $1 / 2$ & $1 / 3$ & 1 & 3 & 3 & 4 & 3 & 7 \\
\hline Aspect (wind) $\left(x_{7}\right)$ & $1 / 4$ & $1 / 6$ & $1 / 4$ & $1 / 6$ & $1 / 2$ & $1 / 3$ & 1 & 3 & 3 & 2 & 5 \\
\hline Flow accumulation $\left(x_{8}\right)$ & $1 / 4$ & $1 / 3$ & $1 / 3$ & $1 / 4$ & $1 / 3$ & $1 / 3$ & $1 / 3$ & 1 & 3 & 2 & 4 \\
\hline Transport $\left(x_{9}\right)$ & $1 / 5$ & $1 / 6$ & $1 / 6$ & $1 / 5$ & $1 / 3$ & $1 / 4$ & $1 / 3$ & $1 / 3$ & 1 & 2 & 3 \\
\hline Distance from Airport $\left(x_{10}\right)$ & $1 / 8$ & $1 / 8$ & $1 / 7$ & $1 / 6$ & $1 / 3$ & $1 / 3$ & $1 / 3$ & $1 / 2$ & $1 / 2$ & 1 & 3 \\
\hline Soil type $\left(x_{11}\right)$ & $1 / 9$ & $1 / 8$ & $1 / 9$ & $1 / 8$ & $1 / 8$ & $1 / 7$ & $1 / 5$ & $1 / 4$ & $1 / 3$ & $1 / 3$ & 1 \\
\hline Column total & 3.55 & 7.87 & 6.42 & 9.68 & 17.96 & 19.39 & 28.37 & 25.08 & 38.83 & 42.33 & 65.00 \\
\hline
\end{tabular}


Table $2 b$. Normalized matrix and significance weight of each criteria

\begin{tabular}{lcccccccccccc}
\hline \multicolumn{1}{c}{ Parameters } & $x_{1}$ & $x_{2}$ & $x_{3}$ & $x_{4}$ & $x_{5}$ & $x_{6}$ & $x_{7}$ & $x_{8}$ & $x_{9}$ & $x_{10}$ & $x_{11}$ & Weight $(\%)$ \\
\hline Land-use $\left(x_{1}\right)$ & 0.28 & 0.25 & 0.47 & 0.31 & 0.22 & 0.21 & 0.18 & 0.16 & 0.13 & 0.19 & 0.14 & 23.03 \\
\hline Slope $\left(x_{2}\right)$ & 0.14 & 0.13 & 0.05 & 0.21 & 0.22 & 0.26 & 0.21 & 0.12 & 0.15 & 0.19 & 0.12 & 16.40 \\
\hline Distance from settlement $\left(x_{3}\right)$ & 0.09 & 0.38 & 0.16 & 0.21 & 0.22 & 0.15 & 0.14 & 0.12 & 0.15 & 0.17 & 0.14 & 17.58 \\
\hline Distance from waterbody $\left(x_{4}\right)$ & 0.09 & 0.06 & 0.08 & 0.10 & 0.17 & 0.10 & 0.21 & 0.16 & 0.18 & 0.14 & 0.12 & 12.95 \\
\hline Groundwater $\left(x_{5}\right)$ & 0.07 & 0.03 & 0.04 & 0.03 & 0.06 & 0.15 & 0.07 & 0.12 & 0.08 & 0.07 & 0.12 & 7.70 \\
\hline Lineament $\left(x_{6}\right)$ & 0.07 & 0.03 & 0.05 & 0.05 & 0.02 & 0.05 & 0.11 & 0.12 & 0.10 & 0.07 & 0.11 & 7.06 \\
\hline Aspect $($ wind $)\left(x_{7}\right)$ & 0.06 & 0.02 & 0.04 & 0.02 & 0.03 & 0.02 & 0.04 & 0.12 & 0.08 & 0.05 & 0.08 & 4.86 \\
\hline Flow accumulation $\left(x_{8}\right)$ & 0.07 & 0.04 & 0.05 & 0.02 & 0.02 & 0.02 & 0.01 & 0.04 & 0.08 & 0.05 & 0.06 & 4.22 \\
\hline Transport $\left(x_{9}\right)$ & 0.06 & 0.02 & 0.03 & 0.01 & 0.02 & 0.01 & 0.01 & 0.01 & 0.03 & 0.05 & 0.05 & 2.67 \\
\hline Distance from Airport $\left(x_{10}\right)$ & 0.04 & 0.02 & 0.02 & 0.02 & 0.02 & 0.02 & 0.02 & 0.02 & 0.01 & 0.02 & 0.05 & 2.24 \\
\hline Soil type $\left(x_{11}\right)$ & 0.03 & 0.02 & 0.02 & 0.01 & 0.01 & 0.01 & 0.01 & 0.01 & 0.01 & 0.01 & 0.02 & 1.28 \\
\hline
\end{tabular}

generated using GIS. The lower values of suitability class 1 and 2 on the maps indicated most suitable areas for landfill siting (Fig. 5). The area in the study region with value 1 was negligible hence the next class of area with suitability class value 2 (more suitable than 3,4 and 5) was considered for extraction of the suitable areas for landfill site.

The final analysis showed that about $12 \mathrm{~km}^{2}$ of the total area $\left(101 \mathrm{~km}^{2}\right)$ is suitable for locating landfill sites. Eleven candidate sites were finalized on the basis of the size of a site greater than 4 ha and are shown in Figure 6.

To make the selection more precise, all the eleven candidate sites were further compared with the three most significant criteria i.e. land-use pattern, distance from the settlement and the distance from surface water bodies. This study proved to be efficient and provide more accurate results. Figure 7 shows the area covered by each type of the land-use for comparative study of the individual suitability of all eleven candidate sites. Each bar in a graph (Fig. 7) represents the area coverage of each candidate site in percentage to make comparison with each other. Candidate sites 7, 8 and 10 had maximum quantity of suitable land and candidate sites 1,2 , and 9 had maximum area located at suitable distance from settlement whereas candidate sites 6,4 and 1 had enough land situated at a suitable distance from surface water bodies.

These sites were ranked based on the area statistics of each attribute of these three criteria individually. Finally these ranks were pooled in a single rank using linear combination of weight derived from AHP (Table 3 ) of the three criteria and their ranks. The calculation step is same as followed for Table 2.

The candidate sites 6, 7 and 8 (Fig. 8) were the most suitable landfill sites in the study area as these sites had high ranking order 1, 2, and 3 respectively (Table 4 ).

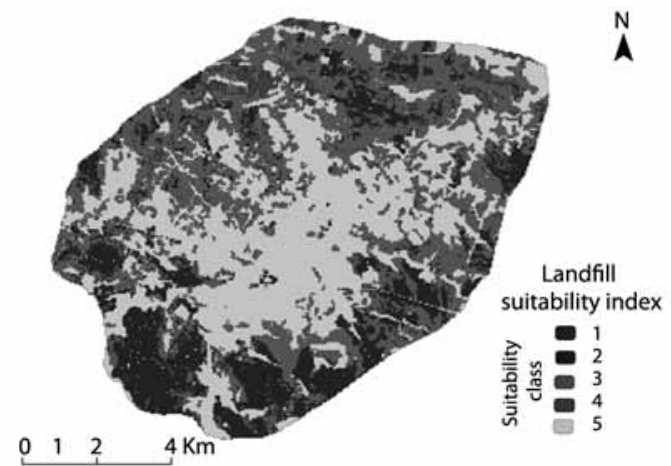

Fig. 5. Landfill suitability index

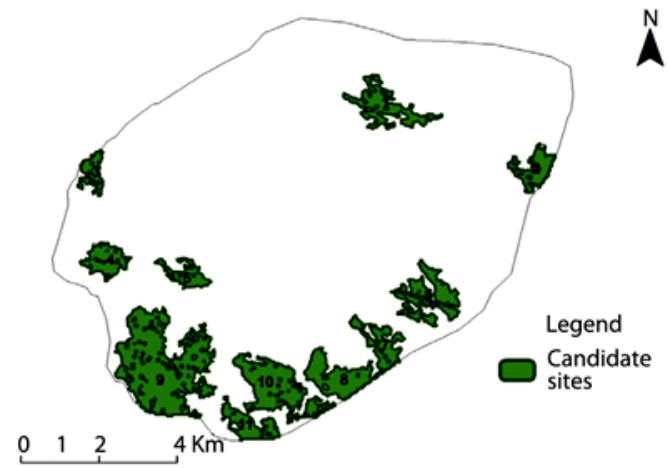

Fig. 6. Selected candidate sites

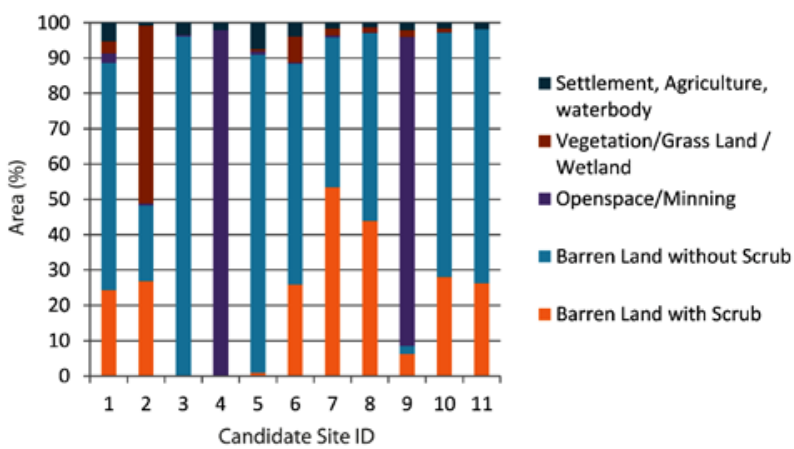

Fig. 7. Comparison of all the candidate sites with respect to land-use 
Table 3(a). AHP for candidate site ranking

\begin{tabular}{lccc}
\hline \multicolumn{1}{c}{ Criteria } & $\left(s_{1}\right)$ & $\left(s_{2}\right)$ & $\left(s_{3}\right)$ \\
\hline Land-use $\left(s_{1}\right)$ & 1 & 4 & 5 \\
\hline Distance from Settlement $\left(s_{2}\right)$ & $1 / 4$ & 1 & 3 \\
\hline Distance from Waterbody $\left(s_{3}\right)$ & $1 / 5$ & $1 / 3$ & 1 \\
\hline Column Sum & 1.45 & 5.33 & 9 \\
\hline
\end{tabular}

Table 3(b). Normalized matrix and significant weight of each criteria for candidate site ranking criteria

\begin{tabular}{lcccc}
\hline Criteria & $\left(s_{1}\right)$ & $\left(s_{2}\right)$ & $\left(s_{3}\right)$ & Weight \\
\hline Land-use $\left(s_{1}\right)$ & 0.69 & 0.75 & 0.56 & 0.67 \\
\hline Distance from Settlement $\left(s_{2}\right)$ & 0.17 & 0.19 & 0.33 & 0.23 \\
\hline Distance from Waterbody $\left(s_{3}\right)$ & 0.14 & 0.06 & 0.11 & 0.10 \\
\hline
\end{tabular}

Table 4. Rank of Candidate Sites

\begin{tabular}{|c|c|c|c|c|c|c|c|c|c|c|c|c|}
\hline & $\begin{array}{c}\text { Candidate } \\
\text { Site ID }\end{array}$ & 1 & 2 & 3 & 4 & 5 & 6 & 7 & 8 & 9 & 10 & 11 \\
\hline \multirow{4}{*}{$\begin{array}{l}\tilde{0} \\
\tilde{\Xi} \\
\tilde{\Xi} \\
\tilde{\Xi} \\
\underline{\Xi} \\
\tilde{\Xi}\end{array}$} & Land-u & 6 & 7 & 8 & 11 & 9 & 5 & 1 & 2 & 10 & 3 & 4 \\
\hline & $\begin{array}{l}\text { Distance } \\
\text { from } \\
\text { Settlement }\end{array}$ & 1 & 2 & 7 & 6 & 11 & 4 & 5 & 9 & 3 & 8 & 10 \\
\hline & $\begin{array}{l}\text { Distance } \\
\text { from } \\
\text { Waterbody }\end{array}$ & 3 & 5 & 8 & 2 & 11 & 1 & 7 & 4 & 6 & 9 & 10 \\
\hline & $\begin{array}{l}\text { Overall } \\
\text { Rank }\end{array}$ & 4 & 6 & 8 & 10 & 11 & 3 & 1 & 2 & 9 & 5 & 7 \\
\hline
\end{tabular}

Candidate sites 6, 7 and 8 had more than $90 \%$ area under barren land and nearly $30 \%$ area was in between a distance of 400 to $600 \mathrm{~m}$ from settlement and more than $40 \%$ area was in between a distance of greater than $400 \mathrm{~m}$. So, the selected sites had enough barren land or quarry, substantially away from the built up area and located at a safe distance from surface water bodies making them more suitable as solid waste disposal sites.

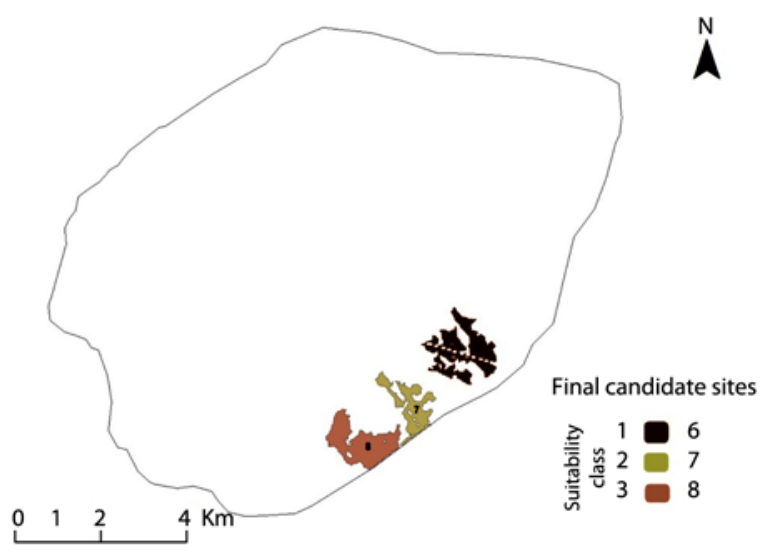

Fig. 8. Final candidate sites

\section{Conclusions}

Landfill site selection is one of the most important components of any MSWM system and needs to be planned scientifically using recent advancements in the spatial sciences. GIS is a very powerful tool and provides a rapid assessment for suitable landfill siting for MSW disposal in a rapidly growing city like Dhanbad. An unscientific siting of a landfill may result in adversely affected surrounding environment. This situation is observed in most developing nations including India. Most cities of developing countries are faced with the improper management of data as one of the limitations. For the selection of landfill sites, eleven criteria were considered relevant to Dhanbad city. Generally more criteria give more precise results, but selecting less important criteria which have negligible impact, make the system very complex. So, the evaluation criteria must be selected based on their impact on the suitability analysis. Environmental criteria are more sensitive due to its control over the leachate transport rate than socio-economic criteria which are important for limiting financial expenditure. In this study, eleven possible landfill sites were identified using GIS that satisfied most of the desirable criteria of locating an environmentally suitable landfill site. The study area is rich in coal reserve and there is a limitation of using geological data as it is not accessible for the present study area and therefore the depth to the bedrock was not considered. Suitable landfill sites were identified using overlay analysis of different layers selected on the basis of AHP applicable for the characteristics of the region. Final landfill suitability maps were generated using WLC and the prioritizing candidate sites have been done by repeating the whole process considering the most desirable factors. The factors which were assigned more weights were compared to select the most appropriate landfill site. The factors considered for comparison study were land-use pattern, distance from the settlement, and the distance from the road network. Out of the 11 candidate sites identified in this study, three "potential landfill" sites were selected as the most acceptable landfill sites with suitability ranking using repetitive application of AHP and WLC considering three most influential parameters affecting landfill siting. The most suitable identified sites for landfill were confirmed by field visits. They were found to be feasible with respect to the environmental criteria. Furthermore, the study could be validated by considering site owernership and the public acceptance study. Insitu field survey such as litholog analysis, soil permeability test, hydrogeological survey should be conducted before finalising the landfill location. This study used secondary coarse resolution data for soil and lineaments data, fine resolution data for the same could give more accurate results. 


\section{Acknowledgements}

The authors acknowledge the support provided by the Department of Environmental Science and Engineering, Indian School of Mines, Dhanbad for carrying out this research work.

\section{Reference}

Achillas, C.; Moussiopoulos, N.; Karagiannidis, A.; Banias, G.; Perkoulidis, G. 2013. The use of multi-criteria decision analysis to tackle waste management problems: A literature review, Waste Management \& Research 31(2): 115-129. http://dx.doi.org/10.1177/0734242X12470203

Allesch, A.; Brunner, P. H. 2014. Assessment methods for solid waste management: A literature review, Waste Management \& Research 32(6): 461-473. http://dx.doi.org/10.1177/0734242X14535653

Baban, S. J.; Flannagan, J. 1998. Developing and implementing GIS-assisted constraints criteria for planning landfill sites in the UK, Planning Practice and Research 13(2): 139-151. http://dx.doi.org/10.1080/02697459816157

Bhushan, N.; Rai, K. 2004. Strategic decision making: applying the analytic hierarchy process. New-York: Springer-Verlag.

Carver, S. J. 1991. Integrating multi-criteria evaluation with geographical information system, Journal of Geographical Information System 5(3): 321-339. http://dx.doi.org/10.1080/02693799108927858

Chang, N.; Parvathinathan, G.; Breeden, J. B. 2008. Combining GIS with fuzzy multi criteria decision making for landfill siting in a fast-growing urban region, Journal of Environmental Management 87(1): 139-153.

http://dx.doi.org/10.1016/j.jenvman.2007.01.011

Charnpratheep, K.; Zhou, Q.; Garner, B. 1997. Preliminary landfill site screening using fuzzy geographic information systems, Waste Management and Research 15(2): 197-215. http://dx.doi.org/10.1177/0734242X9701500207

Chavez, P. S. Jr. 1988. An improved dark object subtraction technique for atmospheric correction of multispectral data, Remote Sensing of Environment 24(3): 459-479. http://dx.doi.org/10.1016/0034-4257(88)90019-3

Chiueh, P. T.; Yu, Y. H. 2006. Assessment on the solid waste management information system in Taiwan, Journal of Environmental Engineering and Management 16(6): 427.

Delgado, O. B.; Mendoza, M.; Granados, E. L.; Geneletti, D. 2008. Analysis of land suitability for the siting of inter-municipal landfills in the Cuitzeo Lake Basin, Mexico, Waste Management 28(7): 1137-1146.

http://dx.doi.org/10.1016/j.wasman.2007.07.002

Demesouka, O. E.; Vavatsikos, A. P.; Anagnostopoulos, K. P. 2014. GIS-based multicriteria municipal solid waste landfill suitability analysis: A review of the methodologies performed and criteria implemented, Waste Management \& Research 32(4): 270-296.

http://dx.doi.org/10.1177/0734242X14526632

Dorhofer, G.; Siebert, H. 1998. The search for landfill sitesRequirements and implementation in Lower Saxony, Germany, Environmental Geology 35(1): 55-65. http://dx.doi.org/10.1007/s002540050292

Eastman, J. R. 2003. IDRISI Kilimanjaro: Guide to GIS and image processing. Worcester: Clark Laboratories, Clark University. $328 \mathrm{p}$.
Gbanie, S. P.; Tengbe, P. B.; Momoh, J. S.; Medo, J.; Kabba, V. T. S. 2013. Modelling landfill location using geographic information systems (GIS) and multi-criteria decision analysis (MCDA): Case study Bo, Southern Sierra Leone, Applied Geography 36: 3-12. http://dx.doi.org/10.1016/j.apgeog.2012.06.013

Gemitzi, A.; Tsihrintzis, V. A.; Voudrias, E.; Petalas, C.; Stravodimos, G. 2007. Combining geographic information system, multicriteria evaluation techniques and fuzzy logic in sitting MSW landfills, Environmental Geology 51(5): 797-811. http://dx.doi.org/10.1007/s00254-006-0359-1

Hopkins, L. D. 1977. Methods for generating land suitability maps: a comparative evaluation, Journal of the American Institute of Planners 43(4): 386-400. http://dx.doi.org/10.1080/01944367708977903

Higgs, G. 2006. Integrating multi-criteria techniques with geographical information systems in waste facility location to enhance public participation, Waste Management \& Research 24(2): 105-117. http://dx.doi.org/10.1177/0734242X06063817

Ionescu, S.; Deac, V.; Corpodean, C. 2011. Risk of exposure to asbestos in case of the mechanical degradation of some asbocement composites, Environmental Engineering and Management Journal 9: 1773-1777.

Jensen, J. R. 1986. Introductory digital image processing: a remote sensing perspective. New Jersey: Prentice-Hall.

Kao, J. J.; Lin, H. Y.; Chen, W. Y. 1997. Network geographic information system for landfill siting, Waste Management \& Research 15(3): 239-253. http://dx.doi.org/10.1177/0734242X9701500303

Kara, C.; Doratli, N. 2012. Application of GIS/AHP in siting sanitary landfill: a case study in Northern Cyprus, Waste Management \& Research 30(9): 966-980. http://dx.doi.org/10.1177/0734242X12453975

Kontos, T. D.; Komilis, D. P.; Halvadakis, C. P. 2003. Siting MSW landfills on Lesvos island with a GIS based methodology, Waste Management \& Research 21(3): 262-277. http://dx.doi.org/10.1177/0734242X0302100310

Kontos, T. D.; Komilis, D. P.; Halvadakis, C. P. 2005. Siting MSW landfills with a spatial multiple criteria analysis methodology, Waste Management 25(8): 818-832. http://dx.doi.org/10.1016/j.wasman.2005.04.002

Lin, H. Y.; Kao, J. J. 1998. A vector-based spatial model for landfill siting, Journal of Hazardous Materials 58(1): 3-14. http://dx.doi.org/10.1016/S0304-3894(97)00116-7

Lukasheh, A. F.; Droste, R. L.; Warith, M. A. 2001. Review of expert system (ES), geographic information system (GIS), decision support system (DSS), and their applications in landfill design and management, Waste $M a$ nagement \& Research 19(2): 177-185. http://dx.doi. org/10.1177/0734242X0101900209

Manual on Municipal Solid Waste Management. 2000. $1^{\text {st }}$ ed. Central Public Health and Environmental Engineering Organisation (CPHEEO), Ministry of Urban Developement, Govenrment of India, New Delhi.

Moeinaddini, M.; Khorasani, N.; Danehkar, A.; Darvishsefat, A. A. 2010. Siting MSW landfill using weighted linear combination and analytical hierarchy process (AHP) methodology in GIS environment (case study: Karaj), Waste Management 30(5): 912-920. http://dx.doi.org/10.1016/j.wasman.2010.01.015 
O'Callaghan, J. F.; Mark, D. M. 1984. The extraction of drainage network from digital elevation data, Computer Vision, Graphics and Image Processing 28(3): 328-344. http://dx.doi.org/10.1016/S0734-189X(84)80011-0

Rathi, S. 2006. Alternative approaches for better municipal solid waste management in Mumbai, Waste Management 26(10): 1192-1200. http://dx.doi.org/10.1016/j.wasman.2005.09.006

Robu, B. M.; Caliman, F. A.; Betianu, C.; Gavrilescu, M. 2007. Methods and procedures for environmental risk assessment, Environmental Engineering and Management Journal 6(6): 573-592.

Saaty, T. L. 1977. A scaling method for priorities in hierarchical structures, Journal of Mathematical Psychology 15(3): 234281. http://dx.doi.org/10.1016/0022-2496(77)90033-5

Schiopu, A. M.; Piuleac, G. C.; Cojocaru, C.; Apostol, I.; Mamaliga, I.; Gavrilescu, M. 2012. Reducing environmental risk of landfills: leachate treatment by reverse osmosis, Environmental Engineering and Management Journal 11(12): 2319-2331.

Şener, B. 2004. Landfill site selection by using geographic information systems. M.Sc Thesis. Middle East Technical University METU, Ankara, Turkey, 114 p. [online], [cited 12 March 2013]. Available from Internet: http://www.rsgis.metu.edu.tr

Şener, B., Süzen, M. L., \& Doyuran, V. 2006. Landfill site selection by using geographic information systems, Environmental Geology 49(3): 376-388. http://dx.doi.org/10.1007/s00254-005-0075-2

Şener, Ş.; Şener, E.; Nas, B.; Karagüzel, R. 2010. Combining AHP with GIS for landfill site selection: a case study in the Lake Beysehir catchment area (Konya, Turkey), Waste Management 30(11): 2037-2046.

http://dx.doi.org/10.1016/j.wasman.2010.05.024
Sharholy, M.; Ahmad, K.; Mahmood, G.; Trivedi, R. C. 2008. Municipal solid waste management in Indian cities - a review, Waste Management 28(2): 459-467. http://dx.doi.org/10.1016/j.wasman.2007.02.008

Siddiqui, M. Z.; Everett, J. W.; Vieux, B. E. 1996. Landfill siting using geographic information systems: a demonstration, Journal of Environmental Engineering 122(6): 515-523. http://dx.doi.org/10.1061/(ASCE)0733-9372(1996)122:6(515)

Simion, I. M.; Ghinea, C.; Maxineasa, S. G.; Taranu, N.; Bonoli, A.; Gavrilescu, M. 2013. Ecological footprint applied in the assessment of construction and demolition waste integrated management, Environmental Engineering and Management Journal 12(4): 779-788.

Sumathi, V. R.; Natesan, U.; Sarkar, C. 2008. GIS-based approach for optimized siting of municipal solid waste landfill, Waste Management 28(11): 2146-2160. http://dx.doi.org/10.1016/j.wasman.2007.09.032

Turkish Solid Waste Control Regulations (TSWCR) 2002. Solid waste control regulation. Ministry of Environment and Forestry of Turkey, Official Gazette No. 24736, Ankara, Turkey.

Wang, G.; Qin, L.; Li, G.; Chen, L. 2009. Landfill site selection using spatial information technologies and AHP: a case study in Beijing, China, Journal of Environmental Management 90(8): 2414-2421. http://dx.doi.org/10.1016/j.jenvman.2008.12.008

Yildirim, V. 2012. Application of raster-based GIS techniques in the siting of landfills in Trabzon Province, Turkey: a case study, Waste Management \& Research 30(9): 949-960. http://dx.doi.org/10.1177/0734242X12445656

Debishree KHAN, M. Sc., Senior Research Fellow, Department of Environmental Science and Engineering, Indian School of Mines, Dhanbad, India. Research interests: application of remote sensing and GIS, solid waste management.

Sukha Ranjan SAMADDER, PhD, Assistant Professor, Department of Environmental Science and Engineering, Indian School of Mines, Dhanbad-826004, India. Research interests: application of remote sensing and GIS in broad based environmental management, solid waste management, groundwater pollution. 